\title{
Health Benefits of Uses and Applications of Moringa oleifera in Bakery Products
}

\author{
Paula García Milla ${ }^{1,2}$, Rocío Peñalver ${ }^{1}$ and Gema Nieto ${ }^{1, *(D)}$ \\ 1 Department of Food Technology, Nutrition and Food Science, Veterinary Faculty, University of Murcia, \\ Regional Campus of International Excellence "Campus Mare Nostrum", Campus de Espinardo, \\ 30100 Espinardo, Spain; ppaulagm@gmail.com (P.G.M.); rocio.penalver@um.es (R.P.) \\ 2 Molecular Microbiology and Food Research Laboratory, Escuela de Nutrición y Dietética, Facultad de \\ Ciencias para el cuidado de la Salud, Universidad San Sebastián, Santiago 8420524, Chile \\ * Correspondence: gnieto@um.es; Tel.: +34-868889624; Fax: +34-868884147
}

Citation: Milla, P.G.; Peñalver, R.; Nieto, G. Health Benefits of Uses and Applications of Moringa oleifera in Bakery Products. Plants 2021, 10, 318 https://doi.org/10.3390/plants10020 318

Academic Editor:

Domenico Trombetta

Received: 27 December 2020

Accepted: 3 February 2021

Published: 6 February 2021

Publisher's Note: MDPI stays neutral with regard to jurisdictional claims in published maps and institutional affiliations.

Copyright: (c) 2021 by the authors. Licensee MDPI, Basel, Switzerland. This article is an open access article distributed under the terms and conditions of the Creative Commons Attribution (CC BY) license (https:// creativecommons.org/licenses/by/ $4.0 /)$.

\begin{abstract}
Moringa oleifera belongs to the Moringaceae family and is the best known of the native Moringa oleifera genus. For centuries, it has been used as a system of Ayurvedic and Unani medicine and has a wide range of nutritional and bioactive compounds, including proteins, essential amino acids, carbohydrates, lipids, fibre, vitamins, minerals, phenolic compounds, phytosterols and others. These characteristics allow it to have pharmacological properties, including anti-diabetic, antiinflammatory, anticarcinogenic, antioxidant, cardioprotective, antimicrobial and hepatoprotective properties. The entire Moringa oleifera plant is edible, including its flowers, however, it is not entirely safe, because of compounds that have been found mainly in the root and bark, so the leaf was identified as the safest. Moringa oleifera is recognised as an excellent source of phytochemicals, with potential applications in functional and medicinal food preparations due to its nutritional and medicinal properties; many authors have experimented with incorporating it mainly in biscuits, cakes, brownies, meats, juices and sandwiches. The results are fascinating, as the products increase their nutritional value; however, the concentrations cannot be high, as this affects the organoleptic characteristics of the supplemented products. The aim of this study is to review the application of Moringa oleifera in bakery products, which will allow the creation of new products that improve their nutritional and functional value.
\end{abstract}

Keywords: Moringa; natural preservatives; bakery products; functional food

\section{Introduction}

Moringa oleifera is a genus of the fast-growing tropical deciduous plant of the Moringaceae family, with thick, tuberous roots, light green leaves and abundant flowering with elongated, pendulous fruits and seeds [1]. It is a native crop of northern India, although it is found in southwest Asia, southwest and northwest Africa and Madagascar. It has long been a part of traditional horticulture, used mainly for ornamental purposes in cities along the Pacific coast of Mexico [2], as well as plantations in Bolivia, Argentina and elsewhere in the world [3]. It has 13 known species, with Moringa oleifera, native to India, being one of the most studied and used for its nutritional, phytochemical and pharmacological properties. According to ayurvedic medicine (traditional and alternative medicine of India) [4], it is attributed properties for the treatment of some diseases, such as asthma, epilepsy, eye and skin diseases, fever and haemorrhoids [5-7]. In fact, it is a medicinal plant traditionally known in the approach to malnutrition and other diseases [8].

It can withstand long periods of drought, growing well in arid and semi-arid areas. According to researchers, it tolerates soils with a $\mathrm{pH}$ between 4.5 and 8, although neutral or slightly acidic $\mathrm{pH}$ is more favourable [9]; it is a very adaptable species, lives about 20 years and reaches a height of 5 to $10 \mathrm{~m}$ in a short period of time, reaching $4 \mathrm{~m}$ in 6 months [10]. It is considered a very versatile plant due to its great capacity to provide edible food, which 
includes different vegetative structures, such as leaves, pod shells, stem, flowers, fruits and seeds. These structures contain bioactive compounds and nutrients (Figure 1), such as phenolic compounds, fatty acids, carbohydrates, fibre, minerals, vitamins and functional peptides with a wide potential to be used in food.

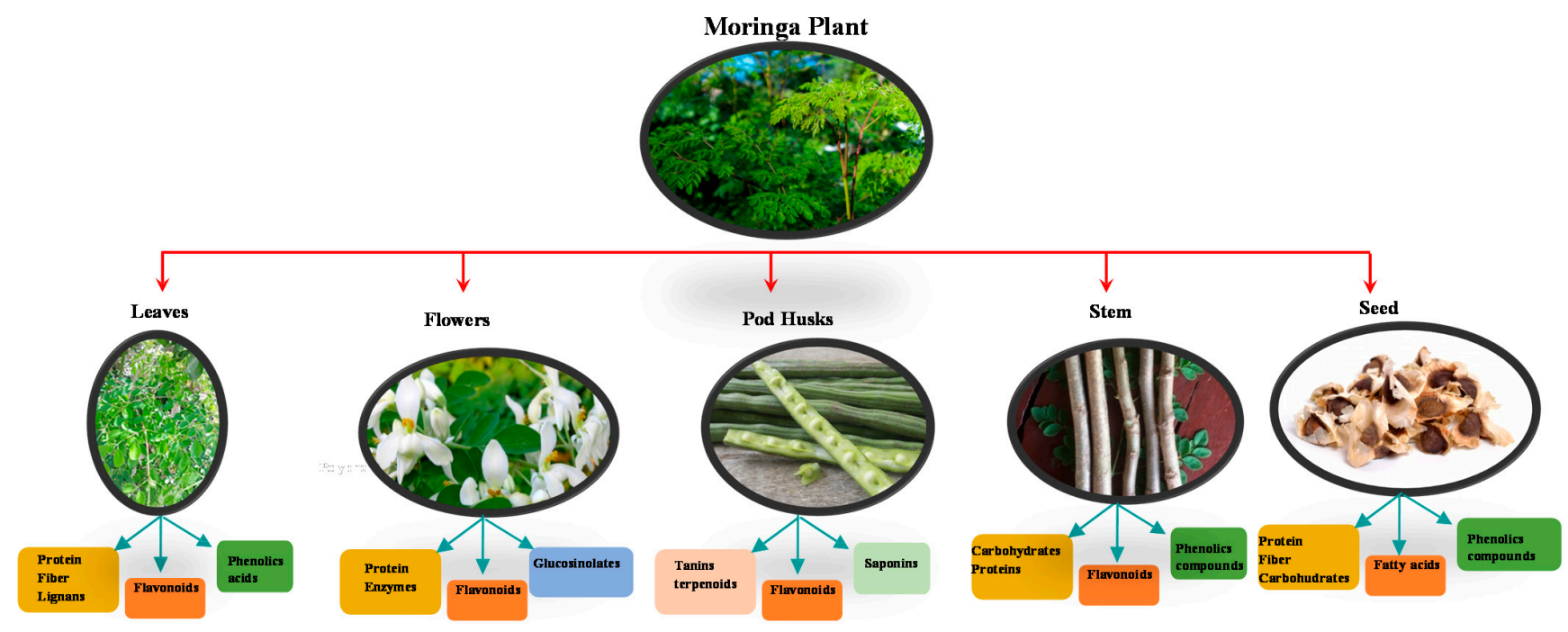

Figure 1. Composition in bioactive compounds of vegetative structures of Moringa oleifera plant.

However, not all of the plant is probably safe, as toxic compounds have been found [11]. On the other hand, its uses are varied, as the seed is used to purify water and the oil from the seeds can be used as a fertiliser [6]. Considering that previous studies have shown that bioactive compounds from herbs and plants could be used for functional food product innovation [11-14]. Moringa oleifera plants could be used for functional food and other industrial food applications [15]. Therefore, Moringa oleifera provides nutrients that benefit health, making it a key food for food security in areas with fewer economic resources [16], this review summarises recent knowledge on bioactive compounds from Moringa oleifera plants and their potential use in the formulation of food products, especially bakery products. The objective of this review is to know the uses and applications of Moringa oleifera in bakery products, in order to know what the quantity or concentration of Moringa oleifera is that allows maintaining the sensory characteristics of the product.

\section{Botanical and Taxonomic Characteristics}

Moringa oleifera belongs to the Moringaceae family, order Capparidales, class Magnoleopsida. It is the best known of the genus Moringa oleifera, which has 13 species [17]. It is identified by its fruit in the form of a long, woody pod, which, when ripe, opens into two leaflets, where it contains the trivalent seeds with longitudinal wings. Its pinnate leaves are divided into leaflets arranged on a rachis [18]. The flowers are grouped in axillary panicles, are bisexual, zygomorphic with five unequal white petals, five sepals, five stamens and several staminodes; they have pedicels and auxiliary inflorescences. The plant has erect stems and tuberous roots [2,19]. It is a tree that can reach 7-12 $\mathrm{m}$ in height and $20-40 \mathrm{~cm}$ in diameter, with an open crown and straight stem [20].

\section{Ethnopharmacological Uses of Moringa oleifera}

Moringa oleifera has been used as a medicine in India since the 18th century BC. Traditional healers used different parts of the plant as traditional medicines. The medicinal uses are numerous and have long been recognised as an Ayurvedic and Unani system of medicine. Almost all parts of the plant: root, bark, gum, leaf, fruit (pods), flowers, seeds and seed oil, have been used to treat various diseases, like skin infections, swelling, anaemia, asthma, bronchitis, diarrhoea, headache, joint pain, rheumatism, gout, diarrhoea, 
heart problems, fevers, digestive disorders, wounds, diabetes, conjunctivitis, haemorrhoids, goitre, earache, measles and smallpox in the indigenous system of medicine $[5,21]$.

\section{Composition of Moringa oleifera}

The composition of Moringa oleifera varies depending on climatic variations, crop management, whether it is cultivated or wild, the state of maturity of the plant at the time of harvesting, the type of post-harvest processing and depends on the growing area, i.e., the land where it is grown [22].

\subsection{Primary Metabolites}

Moringa oleifera leaf is a rich source of minerals, such as calcium, potassium, zinc, magnesium, iron, phosphorus and copper [23], where it is represented in Table 1. One of the characteristics of the leaf is its high protein content, due to the essential amino acids, which constitute about $30 \%$ of its weight, being comparable to milk powder which contains $35 \%$, and is available all year round, as the protein and essential amino acid content is present in the leaves, unlike other plants which contain them in the seeds $[2,24,25]$, reporting a protein content of $29.4 \mathrm{~g}$ protein $/ 100 \mathrm{~g}$ dry weight in the leaves. Thus, Moringa oleifera can be considered a new source of protein to be included in food, like chia seed, with a protein content of $24 \mathrm{~g}$ protein/100 g dry weight [26]. Regarding carbohydrates, its level is lower (8.1\%) [27] compared to the other parts of the plant, as can be seen in Table 2. In addition, fibres were also found, with a value ranging between 18.1 and $21.1 \mathrm{~g} / 100 \mathrm{~g}$ dry weight of the leaves [28].

The leaves are noted for high levels of $\beta$-carotene and provide more vitamin $A$ than carrots and pumpkin [8], however it is not clear whether this vitamin is retained even after drying and grinding the plant. Even so, studies have shown that their consumption is sufficient to counteract the effects of this vitamin deficiency [2]. They are also a good source of B vitamins (quoted from the book tree miracle), among which thiamine, riboflavin and niacin have been found, with a concentration between 0.06 and $0.6 \mathrm{mg} / 100 \mathrm{~g}, 0.05$ and $0.17 \mathrm{mg} / 100 \mathrm{~g}$ and 0.8 and $0.82 \mathrm{mg} / 100 \mathrm{~g}$ for thiamine, riboflavin and niacin, respectively. In the dried leaf, their concentrations were $2.85,22.16$ and $8.86 \mathrm{mg} / 100 \mathrm{~g} \mathrm{DW}$, respectively [29,30]. On the other hand, supplementation with $100 \mathrm{mg} / \mathrm{dL}$ of Moringa oleifera leaf per day has a similar effect to treatment with vitamin $\mathrm{E}$ at $50 \mathrm{mg} / \mathrm{dL}$ per day [8], contains more vitamin $C$ than an orange and more calcium than dairy products, however a significant part of this calcium is present in the form of calcium oxalate crystals, which cannot be used by the body and is eliminated directly without being absorbed [2]. In addition, Moringa oleifera is high in potassium and iron; even more than bananas and spinach respectively [31].

Moringa oleifera seed has a high proportion of monounsaturated/saturated fatty acids (MUFA/SFA), sterols and tocopherols, as well as proteins rich in sulphur amino acids [32] As reported in previous studies, Moringa oleifera seed oils (also called Behen oil, which is the commercial name given to Moringa oleifera oil) have similar fatty acid content and physicochemical parameters to those reported for other vegetable oils and can be considered as a healthy alternative to hydrogenated oils in food formulations. The main fatty acids present in Moringa oleifera oil are behenic, linoleic, stearic, palmitic, oleic, arachidic, linolenic, eicosenoic and heptadecanoic acids [25], with oleic acid being the main unsaturated fatty acid, with $73.5 \%$ in the seed oil [33]; carbohydrate content is $27.5 \%$ [27]. The seeds are a rich source of $\mathrm{Ca}$ and $\mathrm{Mg}$, respectively [25,34].

Of the other edible parts of Moringa oleifera, with respect to carbohydrates, the pods contain $10.4 \%$, stem $18.5 \%$, bark $26.9 \%$ and stem with bark $31.1 \%$ [27]. Karuna et al. [35] found that the part with the highest level of fibre is the root $(45.43 \%)$, compared to the stem $(41.60 \%)$ and bark (25.73\%). Immature pods and flowers are characterized by a higher content of total monounsaturated fatty acids (MUFA, 16-30\%) and are low in PUFA (34-47\%), compared to leaves [36]. The highest $\mathrm{K}$ content is found in vegetative parts and immature pods $[25,34]$. 
Table 1. The nutritional composition of the leaf of Moringa oleifera.

\begin{tabular}{|c|c|c|c|c|}
\hline Minerals (mg) & Fatty Acids \% & $\begin{array}{l}\text { AA Essentials } \\
\text { (mg) }\end{array}$ & Vitamin & Bioactive Molecules (mg) \\
\hline Р 112.1 & C16:0 23.3 & His $700-1357$ & $\begin{array}{c}\text { Vitamin A } \\
11,300-23,000 \text { UI }\end{array}$ & $\beta$-carotene $6.6-17.6 \mathrm{mg}$ \\
\hline Mg 10.6 & C16:1 0.4 & Thr 790-2197 & Vitamin C $18.7-140 \mathrm{mg}$ & $\alpha$-Tocopherol 74.5-122.1 \\
\hline Na 224.1 & C18:0 4.1 & Tyr 480-1880 & Riboflavin $22.6 \mathrm{mg}$ & Thiamine $2.85 \mathrm{mg}$ \\
\hline K 2071.9 & C18:1 6.27 & Val 1130-2758 & Niacin $8.86 \mathrm{mg}$ & $\begin{array}{c}\text { Polypherols } 2.10-12.2 \\
\text { mgGAE /mg }\end{array}$ \\
\hline Mn 8.37 & C18:2 6.11 & Met + Cys $140-835$ & & Flavonoids $5.1-12.2 \mathrm{mg} / \mathrm{g}$ \\
\hline $\mathrm{Cu} 0.95$ & C18:3 56.9 & Leu $1750-4289$ & & Myricetin $5.8 \mathrm{mg} / \mathrm{g}$ \\
\hline S 137 & C20:0 0.21 & Phe 890-2714 & & Quercetin $0.21-7.6 \mathrm{mg} / \mathrm{g}$ \\
\hline $\mathrm{Cr}<0.5$ & $\mathrm{C} 22: 00.70$ & Lys $1325-1530$ & & Kaempferol 4.6 mg/g \\
\hline $\mathrm{Mb} 0.75$ & & & & Gallic Acid 1.03-1.34 mg \\
\hline $\mathrm{Ni}<0.5$ & & & & Chlorogenic Acid $1.8-6.97 \mathrm{mg} / \mathrm{g}$ \\
\hline \multirow[t]{4}{*}{ Se 2.71} & & & & Glucosinalates $21.84-59.50 \mathrm{mg} / \mathrm{g}$ \\
\hline & & & & Tannins $132-1200 \mathrm{mg}$ \\
\hline & & & & Oxalates $430-1600 \mathrm{mg}$ \\
\hline & & & & Phytates $250-2100 \mathrm{mg}$ \\
\hline
\end{tabular}

Source José J., García L. [16]; Castro-López et al. [37]; Rodríguez-Pérez et al. [38].

Table 2. Nutritional composition of Moringa oleifera edible parts.

\begin{tabular}{|c|c|c|c|}
\hline Component/100 g Dry Weight & Leaves & Immature Fruit Pericarp & Seeds \\
\hline \multicolumn{4}{|c|}{ Macronutrients } \\
\hline Energy (kcal) & $205-295.6$ & 178.2 & 564.5 \\
\hline Protein $(\%)$ & 19-27.1 & $17.2-19.3$ & $32.9-38.3$ \\
\hline Lipids (\%) & $4.7-5$ & $0.4-1.3$ & $30.8-44.8$ \\
\hline Fiber $(\%)$ & 7.9-19.2 & $22.6-46.8$ & $4.9-15.9$ \\
\hline Carbohydrates (\%) & $27-51.7$ & $21-51$ & $14.4-16$ \\
\hline \multicolumn{4}{|c|}{ Minerals } \\
\hline Calcium (mg) & $1.875-2.076$ & $12.5-29$ & 76.9 \\
\hline Iron (mg) & $27.8-38$ & $2.3-5.3$ & 13.7 \\
\hline \multicolumn{4}{|c|}{ Fatty Acids } \\
\hline C18:1 Olecic Acid & 6.27 & 18 & $67.9-78$ \\
\hline \multicolumn{4}{|c|}{ Others: } \\
\hline Ascorbic Acid (vit c) (mg) & $18.7-140$ & 871 & 84.5 \\
\hline Chlorophyll (mg) & 126.8 & - & - \\
\hline
\end{tabular}

Source José J., García L. [16]; Castro-López et al. [37]; Rodríguez-Pérez et al. [38].

\subsection{Secondary Metabolites}

The different parts of Moringa oleifera are good sources of glucosinolates, flavonoids and phenolic acids [25,39], carotenoids [40], tocopherols [41]. Alkaloids, saponins, tannins, steroids, phenolic acids, alkaloids, carotenoids, polyphenols, isothiocyanates, phytates, glucosinolates, flavonoids and terpenes can be found in the Moringa oleifera leaf [7]. Among the glucosinolates, benzyl 4-O-( $\alpha$-L-rhamnopyranosyloxy)-glucosinolate is the most predominant (glucomoringin) [25].

Its leaves include 11 phenolic acids (gallic acid, caffeic acid, chlorogenic acid, ocoumaric acid, p-coumaric acid, ellagic acid, gentisic acid, sinapic acid, syringic acid) [42,43] and their derivatives (coumaroylquinic acids and their isomers, feruloylquinic and caffeoylquinic), 26 flavonoids (present mainly as flavonol and glycoside: quercetin, rhamnetin, campferol, apigenin and myricetin [7]. Flavonoids include flavonol glycosides (glycosides, rutinosides and malonylglycosides) of quercetin "kaempferol" $0.05-0.67 \%$ ) isorhamnetin and lignans (isolariciresinol, medioresinol, epipinoresinol glycosides and secoisolariciresinol) [37-39]. Furthermore, there is a difference according to geographical 
area, showing a higher phenolic content in Pakistan than in India, Thailand, Nicaragua and even in the United States $[14,21]$. The flavonoid composition is higher in the leaves than in the seeds, ranging from 2000 to $12,200 \mathrm{mg}$ per dl of Moringa oleifera leaf.

Moringa oleifera seed contains phytosterols, the most abundant of which are $\beta$-sitosterol, stigmasterol and campesterol [3,44]. Alkaloids, saponins, phytates, tannin [45] and phenolic compounds (quercetin and p-hydroxybenzoic acid) [46] can also be found.

The seed is oleaginous and has aleurone sources with a lectin fraction, is an oil that must be refined to be consumed and contains a similar composition to oleic acid, however, the composition may vary according to the geographical location of the plant [3]. Seeds are a good source of glucosinalates $(8-10 \%)$, glycosylate isothiocyanate, $4-(\alpha-\mathrm{L}-$ rhamnosyloxy) benzyl ITC [47] and 4-O-( $\alpha$-L-rhamnopyranosyloxy)-benzylglucosinolate (glucomoringin) [25,47].

In other edible parts of Moringa oleifera, more than 102 bioactive compounds have been identified in the root, while 74 essential oils have been identified in the flowers. In addition, both the peel and the dried pod of Moringa oleifera fruit contain high levels of polysaccharides and glucans; $28 \%$ in the peel and $32 \%$ in the pod [48]. Glucosinolates have also been found, of which 4-O-( $\alpha$-L-rhamnopyranosyloxy)-benzylglucosinolate (glucomoringin) is the most predominant in the stem, flowers and pods of Moringa Oleifera [25,47]. Although in the roots, benzyl glucosinolate (glucotropaeolin) is the most prominent [49], flavonoids, notably flavonol glycosides (glycosides, rutinosides, and malonylglycosides) of quercetin [kaempferol isorhamnetin] are also present in various parts of the plant, except in the roots and seeds [39].

Table 1 highlights the nutritional composition of the edible parts of Moringa oleifera and Table 2 highlights the nutritional composition of the Moringa oleifera leaf, since this plant organ is the most studied and most consumed [29], which concentrates most of the nutrients [8].

\section{Biological Effects of Moringa oleifera}

The bioactive compounds (Figure 1) present in Moringa oleifera confer properties associated with disease prevention and treatment, such as antimicrobial [50], anti-inflammatory [51], anticancer, antidiabetic, antioxidant, hepatoprotective and cardioprotective [52-54]. Primary and secondary metabolites may also be involved in these applications. Primary metabolites are proteins, polysaccharides and lipids involved in physiological functions. Among them, polysaccharides and fibres are the main compounds showing positive effects on chronic diseases such as cancer, cardiovascular diseases, diabetes and obesity. On the other hand, secondary metabolites are minor molecules, such as phenolic compounds, halogenated compounds, sterols, terpenes and small peptides. Most of the phytochemicals reported in Moringa oleifera offer potential in the prevention and treatment of diseases.

The anti-inflammatory effect is due to the content of flavonoids, alkaloids, tannins and glycosides, among which quercetin appears to inhibit NF-KB activation, producing an antiinflammatory effect [55]. Other compounds with an anti-inflammatory effect include kaempferol derivatives, flavonol glycosides [56,57], aurantiamide acetate, 1,3-dibenzylurea [58,59], diterpenes, $\alpha$ - and $\beta$-amyrin [60], benzaldehyde 4-0- $\beta$-glucoside [56,57], $\beta$-sitosterol [43], rutin [61], and glucosinolate, mainly attributed to the glycosylate isothiocyanate, $4-(\alpha$-L-rhamnosyloxy) benzyl ITC, resulting from myrosinase [47]. Moringa oleifera reduces inflammation by suppressing inflammatory enzymes and proteins in the body, and leaf concentrate can significantly reduce inflammation in cells [62].

The antimicrobial effect provided essential oils from the leaves and alcoholic extracts of the seeds. In fact, Chuang et al. [48] demonstrated this activity of the leaf and leaves against dermatophytes such as Trichophyton rubrum and Trichophyton mentagrophytes [48]. In addition to these compounds, other compounds have been found that also produce this effect, 4( $\beta \mathrm{L}$-rhamnosyloxy) benzyl isocyanate or pterigospermine,4( $\beta$-D-glucopyranosyl-1 $\rightarrow 4$ - $\beta$-1-ramnopyranosyloxy),benzyl thiocarboxamide,(-)-Catechin, phenylmethanamine, $4 \beta$-D-glucopyranosyl-1->4 $\beta$-L-rhamnopyranosyloxy)-benzyl iso- 
cyanate, niazirine $[58,63,64]$ and glucosinolate mainly attributed to the glycosylate isothiocyanate, $4-(\alpha$-L-rhamnosyloxy) benzyl ITC, resulting from myrosinase [47].

Phenolic compounds have been associated with the antimicrobial and antifungal activities of Moringa oleifera extracts [65], the leaves being the organs with the highest amount of these compounds. Regarding the antimicrobial effect of Moringa oleifera plants when included in food, Moringa Oleifera contributes to control the growth of undesirable microorganisms, due to low $\mathrm{pH}$ values and the presence of pterigospermin [66]. The roots of Moringa oleifera have antibacterial properties and are described to be rich in antimicrobial agents. The bark extract has been found to have antifungal activities, while the juice of the bark and stem show an antibacterial effect against Staphylococcus aureus [67].

Studies have shown the anticarcinogenic effect of several compounds, namely glycosylated isothiocyanate, benzyl carbamate niazimycin and $\beta$-sitosterol, which have antitumour properties against lung, breast, skin, oesophageal and pancreatic cancer. These compounds are found in high concentrations in the leaves and seeds of the plant [68]. Moringa oleifera is rich in ascorbic acid, which provides an anti-diabetic effect by aiding insulin secretion, and another compound found in Moringa Oleifera that produces this effect is myricetin [69,70].

Antioxidants are popular because they scavenge free radicals that cause oxidative stress, cell damage and inflammation. Moringa oleifera contains antioxidants called flavonoids, polyphenols and ascorbic acid in the leaves, flowers and seeds [71]. Studies have shown that the plant is rich in polyphenols, which gives it a high antioxidant capacity. The compounds in Moringa oleifera that provide this activity are feluric, gallic and ellagic acids, $\beta$-sitosterol, myricetin, niazimycin, niacimicin A and B, tocopherols: $\alpha$-tocopherol, $\delta$ tocopherol, $\gamma$-tocopherol, vanillin, kaempferol, quercetin, $\beta$-carotene (-)-catechin, astragalin and isoquercetin $[58,59,61,70,72-77]$.

Moringa oleifera plays an important role in protecting the liver from damage, oxidation and toxicity due to the high concentrations of polyphenols in its leaves and flowers. Moringa oleifera oil can also restore liver enzymes to normal levels, reducing oxidative stress and increasing protein content in the liver. The flowers and roots of the Moringa oleifera plant contain a compound called quercetin, which is known to protect the liver [78]. Other compounds contained in the plant with this activity are $\beta$-sitosterol, quercetin and some of its glycosides, rutin [61,75] and flavonoids, which also prevent lipid oxidation [79].

Moringa oleifera leaves and seeds have been found to help lower blood pressure; this is due to compounds called glycosides [78], and in the leaves it is also due to N- $\alpha$-Lrhamnophyranosyl vincosamide [61]. Moringa oleifera leaf extract has also been found to significantly reduce cholesterol levels due to the action of $\beta$-sitosterol [78].

\section{Toxic or Adverse Effects}

Moringa oleifera is not entirely safe, as many studies have found various compounds that have been associated with major liver, kidney, haematological and other diseases. Roasted Moringa oleifera seeds contain potential mutagens such as 4-( $\alpha$-lramnopyranosyloxy)benzylglucosinolate, which increase the proportion of micronucleated polychromatophilic erythroblasts, indicative of some degree of genotoxicity [80]. The leaf has a high concentration of saponins, which can be potentially harmful for vegetarians, as their consumption reduces the bioavailability of divalent and trivalent metals such as $\mathrm{Zn}$ and $\mathrm{Mg}$ [81]. Moringin alkaloids, spirochin and the phytochemical benzothiocyanate have been found in the root and bark, toxic substances that predominate in the root and bark; the leaf was therefore identified as the safest edible part [11].

\section{Applications of Moringa oleifera in Food Industry}

Moringa oleifera has several uses due to its composition. The seed powder is used to purify water, eliminating a large amount of suspended material in rivers and turbid waters, making it a natural coagulant for water treatment. The oil from the seeds can be used as a fertiliser in plantations to encourage the growth of other species; it is also used for cosmetics such as soaps and perfumes [6], and even for the production of biodiesel [31]. 
Moringa oleifera extracts can be used to produce zeatin effective for plant development, increasing crop yields [82]. In addition to these applications, Moringa oleifera has been used in food, for example, in Mexico as an ingredient to partially replace fishmeal in tilapia feed, due to its protein and carbohydrate content [83].

\section{Use of Moringa oleifera in Bakery Products}

The use of Moringa oleifera in food can be very beneficial; some researchers indicate that food products can be enriched with Moringa oleifera by providing vitamins, minerals, essential amino acids and oils in order to improve their nutritional value [15] (Table 3 and Figure 2).

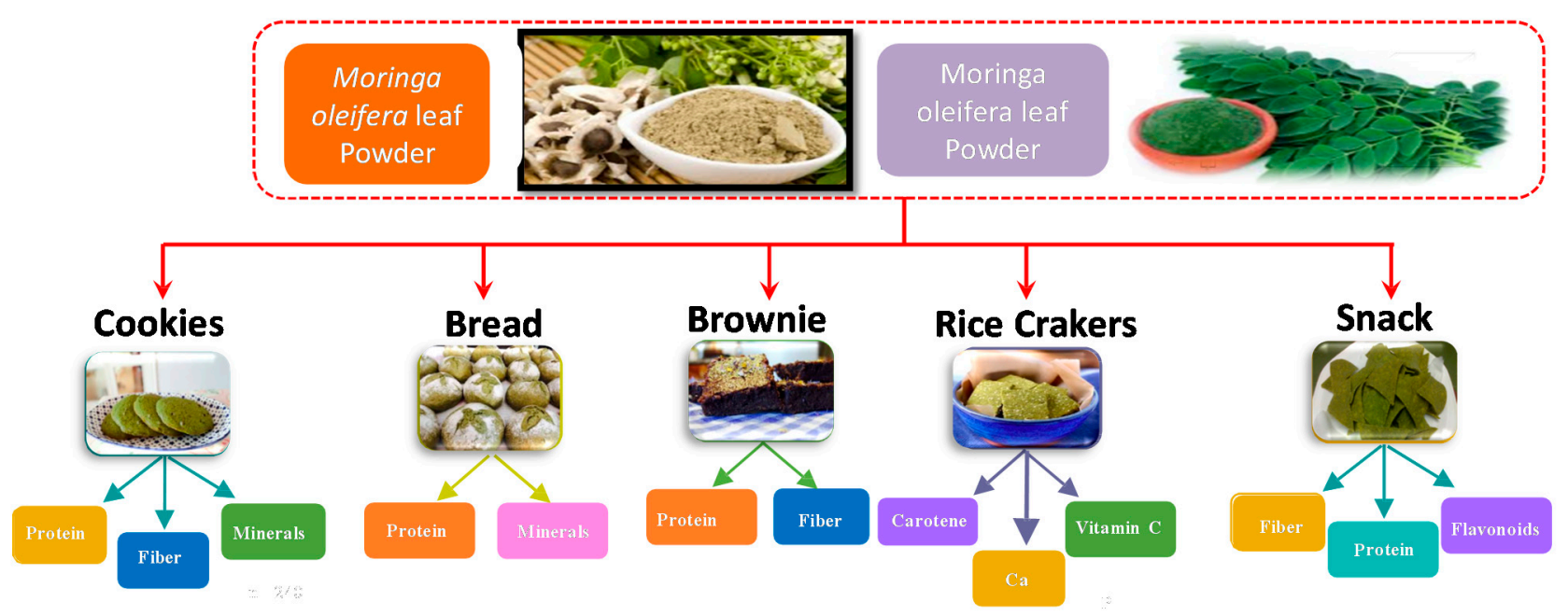

Figure 2. Applications of Moringa oleifera in bakery industry.

Supplementation of Moringa oleifera powder in cereal porridge has been shown to improve the nutritional value by increasing the vitamin A content by up to 15 times. In the white maize variety, the protein content by fortification increased by $94 \%$ with $15 \%$ Moringa oleifera powder and for the yellow maize variety, the protein content increased by $44 \%$ [24].

However, many studies have shown that products formulated with Moringa oleifera powder in high concentrations may be generally unacceptable to most consumers [24]. Domenech et al. [1] reported that most Moringa oleifera is used almost exclusively in breads, biscuits and meat products, with its nutritional, technological and preservative purposes, respectively [1].

Moringa oleifera supplementation has a nutritional purpose, although it can provide other benefits to the product, such as improved digestibility [15], dough stability, antioxidant capacity, preservation, among other benefits associated with the plant [1]. The use in bread and biscuits is a very useful strategy to make up for nutritional deficiencies, due to the high consumption of these foods. In addition, the food industry has tried to reduce the consumption of wheat flour in bakery products, in order to deliver foods that provide better nutritional characteristics, including reduced gluten, and for this, Moringa oleifera seems to be an option [84].

According to Ogunsina et al. [84], the incorporation of Moringa oleifera seed flour affects the organoleptic properties of different breads and biscuits; however, these differences are not significant when used in a ratio of $90 \%$ flour and $10 \%$ Moringa oleifera for bread and $80 \%$ flour and $20 \%$ Moringa oleifera for biscuits. Moreover, the taste was typical of Moringa oleifera seed, but acceptable in bread and the nutritional composition improved in both products, increasing the levels of protein, iron and calcium [84].

Chizoba et al. [85] also developed biscuits, substituting wheat flour with Moringa oleifera leaf flour; their results showed that the indicated proportion to maintain acceptable 
sensory characteristics and attributes is $90 / 10$, i.e., to incorporate $10 \%$ of Moringa oleifera flour not exceeding $20 \%$ according to the authors [85].

The incorporation of Moringa oleifera seed meal in biscuits is reported to improve protein intake, increasing it by $45 \%$ to $90 \%$ if the addition of Moringa oleifera is $10 \%$ or $20 \%$ respectively. In the case of rice cakes, the addition of Moringa oleifera at $5 \%$ (freshly harvested) to $14 \%$ (dried) increases protein by approximately $26 \%$ [15].

Rabie et al. [86] also made biscuits fortified with Moringa oleifera leaf powder and seed powder in different concentrations, ranging from $2.5 \%$ to $7.5 \%$. Their results found that supplementation with Moringa oleifera leaf powder has a higher amount of protein, ash, crude fibre, dietary fibre and minerals, while seed powder is characterised by a higher content of fat, protein, dietary fibre and minerals, and when mixed, a higher amount of essential amino acids was achieved, and when compared to the control, the biscuits with Moringa oleifera incorporation showed a lower carbohydrate content.

In relation to the physical characteristics, there is an increase in weight with a reduction in the volume and diameter of the biscuits, concluding that the best concentration to improve the nutritional characteristics without altering their organoleptic characteristics was $5 \%$ for the incorporation of leaf and seed powder and $2.5 \%+5 \%$ in the case of mixing leaf and seed powder respectively [86].

Most of the evidence related to the incorporation of Moringa oleifera in cakes is associated with the consumption of biscuits, and in all reports, the results are similar. Supplementation increases nutritional value but affects physical characteristics, decreasing volume and colour in some instances; this was also demonstrated by a study by Nutan Narwal et al. [87].

The same would be true for the preparation of brownies and cakes with wheat flour, according to Santos et al. [88], who incorporated 5\% and 10\% Moringa oleifera leaf flour in chocolate brownies, indicating that the samples improved the nutritional value by increasing the ash content with a lower lipid contribution in relation to the control. A feature not mentioned in previous studies with biscuits is that the brownie showed the acidity of the product. The researchers concluded that there is no major difference between $5 \%$ and $10 \%$, as similar results were obtained in both cases [88].

Whereas, in the wheat flour cake, the value of protein, moisture, crude fiber, total ash increased, with a reduction in lipids and carbohydrates, concluding that the cake sample with the addition of $4 \mathrm{~g}$ of Moringa oleifera was the most acceptable in terms of colour, flavour, aroma and overall acceptability [89].

In the case of bakery products, the use of Moringa oleifera powder in wheat flour bread dough as in other products increases the nutritional value, the protein and crude fiber content of wheat bread flour enriched with 5\% Moringa oleifera powder has been found to increase from approximately $17 \%$ to $54 \%$ and $56 \%$ to $88 \%$ respectively. It should be noted that this improvement is accompanied by poor sensory properties, such as crust and crumb colour, as well as product weight and height [15].

Specifically for the case of whole wheat bread, El-Gammal et al. [90] added Moringa oleifera in different concentrations $(5 \%, 10 \%, 15 \%$ and $20 \%)$; the results obtained indicated that Moringa oleifera leaf powder contained high amounts of protein and crude fibre, in addition to some essential minerals such as calcium, magnesium, phosphorus and iron. When Moringa oleifera was added to the preparation of wholemeal sliced bread, the protein content increased to $21.85 \%$, the ash content (5.21\%) and carbohydrate content decreased by $59.34 \%$, and the intake of magnesium, calcium and iron increased compared to the control.

In relation to the undesirable effects of Moringa oleifera in bread incorporation, it negatively affects farinograph and extensometer values. Although there was an improvement in nutritional value, the acceptability of all loaf bread samples decreased with increasing levels of Moringa oleifera powder concentration, especially the loaf bread with 15 and 20\%.

On the other hand, there are modifications in texture, taste, chewiness, elasticity of all samples compared to the control, however the researchers conclude that the best 
concentration to add to sliced bread is 5 or $10 \%$, thus obtaining an increase in nutritional value with acceptable sensory characteristics [90].

Similar results were obtained by Bolarinwa et al. [91], who added Moringa oleifera seed powder to bakery products, increasing the protein value from 8.55 to $13.46 \%$, ash from 0.63 to $1.76 \%$, lipids from 7.31 to $15.75 \%$, fibre from 0.08 to $0.62 \%$, vitamin A from 50 to $74 \%$, with a reduction in moisture from $22.9 \%$ to $20.01 \%$ and carbohydrates from $57.68 \%$ to $46.73 \%$, also highlighting the increase in calcium, iron, phosphorus, and potassium in all its breads. Sensory evaluation results indicated that bread enriched with 5\% Moringa oleifera seeds was not significantly different from the $100 \%$ wheat flour control [91].

Finally, while Devisetti et al. [92] evaluated the effect of Moringa oleifera leaf flour in sandwiches reaching similar conclusions, the protein content in puffed sandwiches increased, presenting $21.6 \mathrm{~g}$ in $100 \mathrm{~g}$ of product; while dietary fibre was presented at $14.8 \mathrm{~g}$ per $100 \mathrm{~g}$ of product, there was also a reduction in fat content of $3.7 \mathrm{~g}$ per $100 \mathrm{~g}$ of product with a high presence of phenolic compounds and flavonoids. In relation to the sensory characteristics of the sandwiches, an acceptable result was obtained in terms of texture [92]. 
Table 3. Results on the applicability of Moringa oleifera in bakery products and its effect on product quality.

\begin{tabular}{|c|c|c|c|c|}
\hline Bakery Products & Parts Used & $\begin{array}{l}\text { Moringa oleifera } \\
\text { Application/Concentration Used }\end{array}$ & Main Results/Conclusions & Reference \\
\hline Cookies & $\begin{array}{l}\text { Moringa oleifera leaves and seeds; } \\
\text { and a combination of both. }\end{array}$ & $2.5 \%, 5.0 \%, 7.5 \%$ & $\begin{array}{l}\text { Moringa oleifera raised the nutritional value } \\
\text { highlighting the amount of protein, ash, fibre } \\
\text { and minerals. In addition, it showed an } \\
\text { increase in weight without increasing the } \\
\text { volume of the cookies compared to the control. }\end{array}$ & [2] \\
\hline Bread and cookies & Moringa oleifera seed flour (MSF). & $10 \%, 20 \% 30 \%$ & $\begin{array}{c}\text { respectively had more protein, iron and } \\
\text { calcium. }\end{array}$ & [23] \\
\hline Cookies & Leaf flour (LF) & $10 \%, 20 \%, 30 \%, 50 \%$ & $\begin{array}{l}\text { Incorporation at } 10 \% \text { of LF showed better } \\
\text { sensory attributes; however, acceptability } \\
\text { decreased as Moringa oleifera levels increased. } \\
\text { Moringa oleifera supplementation at } 5 \% \text { of LF }\end{array}$ & [26] \\
\hline Cookies & Leaf flour (LF) & $5 \%$ & $\begin{array}{l}\text { raised the nutritional value of proteins and ash, } \\
\text { showing a lower content of carbohydrates. }\end{array}$ & [48] \\
\hline Cookies & Leaf flour (LF) & $0 \%, 10 \%, 20 \%, 30 \%, 50 \%$ & $\begin{array}{l}\text { The best acceptability in wheat flour biscuits } \\
\text { supplemented with Moringa oleifera was shown } \\
\text { by the concentration at } 10 \% \text { of LF }\end{array}$ & {$[85,93]$} \\
\hline Bread & Leaf powder (LP) & $5 \%, 10 \%, 15 \%, 20 \%$ & $\begin{array}{l}\text { Supplementation of LP in bread raised the } \\
\text { nutritional characteristics of proteins, ash and } \\
\text { minerals; however, the carbohydrate content } \\
\text { decreased. The acceptability decreases as the } \\
\text { incorporation of Moringa oleifera increases, so } \\
\text { the greater acceptability is at } 5 \% \text { and } 10 \% \text { of LP. }\end{array}$ & [79] \\
\hline Bread & Seed powder (SP) & $0-20 \%$ & $\begin{array}{l}\text { The results showed an increase in the value of } \\
\text { proteins, minerals, ash, lipids, and fibre; } \\
\text { however, there was a decrease in the value of } \\
\text { carbohydrates. There were no sensory } \\
\text { differences with the control when } \\
\text { incorporating } 5 \% \text { of SF. }\end{array}$ & [65] \\
\hline
\end{tabular}


Table 3. Cont.

\begin{tabular}{|c|c|c|c|c|}
\hline Bakery Products & Parts Used & $\begin{array}{l}\text { Moringa oleifera } \\
\text { Application/Concentration Used }\end{array}$ & Main Results/Conclusions & Reference \\
\hline Snack & Leaf powder (LP) & $20 \%$ & $\begin{array}{l}\text { Snacks increased their nutritional value in } \\
\text { protein and fibre, showing a low amount of fat. } \\
\text { Furthermore, flavonoids were found in the } \\
\text { final product. }\end{array}$ & {$[66]$} \\
\hline Rice crackers & Moringa leaves (ML) & $1 \%, 2 \%$ y $5 \%$ & $\begin{array}{l}1 \% \text { and } 2 \% \text { of ML had higher levels of } \\
\beta \text {-carotene, vitamin C, and calcium than the } \\
\text { control. Sensory scores were comparable to } \\
\text { control even at the end of the storage test. }\end{array}$ & [94] \\
\hline Bread & Moringa leaf powder (MLP) & $0 \%, 1 \%, 2 \%, 3 \%, 4 \%$ y $5 \%$ & $\begin{array}{l}\text { The nutritional composition of proteins, ash, } \\
\text { fibre, minerals and } \beta \text {-carotene improved. } \\
\text { Acceptability decreased when Moringa oleifera } \\
\text { supplementation increased, affecting the bread } \\
\text { physical and sensory attributes. }\end{array}$ & [93] \\
\hline
\end{tabular}




\section{New Trends}

New trends in the use of Moringa oleifera in bakery products focus on the preservation of its antioxidant power and on the use of dietary supplements in case of nutritional deficiency situations. In this context, according to the nutritional evaluation, it can be concluded that these components can be used as nutraceuticals [95-98]. The study of molecules of protein nature with bioactive effects on human health, such as antiproteolytic, procoagulant, antidiabetic, antihypertensive and anti-inflammatory properties, opens up new strategies for the design of nutritional supplements and the design of functional foods. This plant is also economical in all respects and has been used by many people due to its many advantages. Today, there is a great demand for plant-based medicine, food supplements, health products, pharmaceuticals, cosmetics, etc. in the national and global market. However, most of the quality of food supplements has not been well evaluated. In addition, there are some types of conventionally used foods, which have some ethnopharmacological importance, but have not been clinically tested. The main mission of this research is to develop the scientific rationale behind their use. This effort aims to explore the therapeutic uses of a food plant, which has medicinal importance in a wide range. The result shows that the plant provides a tremendous source of micronutrients and macronutrients. Therefore, it can be further explored for the development of nutritional supplements in the future, which may be useful to treat various diseases and thus promote a better quality of life.

On the other hand, current research has sought to replace wheat flour largely or entirely with Moringa oleifera, to obtain a gluten-free product that also has unique nutritional characteristics. Currently, the trend in the use of Moringa oleifera aims to improve the nutritional characteristics of fortified products, but also claims to be an excellent supplement for the treatment of various diseases, creating nutritious and nutraceutical foods [99].

\section{Concluding Remark}

Taking into account all the considerations outlined in this review, it is important to note that bioactive compounds from Moringa oleifera have a potential application in food, especially in bakery products. However, there are scarce results regarding the isolation of phytochemical compounds to identify new natural bioactive agents from Moringa oleifera plants and to better understand the role of these compounds in the food matrix. The study of these molecules is a starting point for a better understanding of the role in the food matrix and for a correct technological, nutritional and sensory development of functional foods.

In addition, the stability of nutrients and bioactive compounds in bakery products should be studied. Although several studies have reported on the functional properties of bioactive compounds, there are not enough studies on the digestibility and bioavailability of these bioactive compounds in both in vivo and in vitro systems. Therefore, more clinical trials should be conducted to demonstrate the functional properties of these bioactive compounds present in Moringa oleifera.

Because it is important to consider that not all of the plant is $100 \%$ safe and that there are parts that can eventually harm people's health. The most toxic part of Moringa oleifera is the bark and the root, and the safest part is the leaves; it is important to test their toxicity. In addition, sensory analysis is mandatory before developing the food matrix, because significant alterations in taste and flavour could occur if the level of Moringa oleifera is not adequate. Alterations in sensory characteristics can certainly be a barrier to food consumption.

\section{Conclusions}

This review aimed to highlight the bioactive compounds of Moringa oleifera plants and recent approaches to functional applications and the influence of these biocompounds on the functional characteristics of bakery products. The main food products based on Moringa oleifera plants were found to be high in dietary fibre and low in fat, suggesting that this plant can be used in the formulation of low-calorie food products. 
The incorporation of Moringa oleifera will increase the nutritional value, improving the contribution of macro and micronutrients, of which proteins, fibres, vitamins and minerals are the most important, however, there is a difference when using the leaves versus the seed of Moringa oleifera, as the latter will increase the value of lipids, which is not a characteristic of the leaves. In all cases, high concentrations alter the physical and sensory characteristics of the supplemented products. In most studies, Moringa oleifera has been used in bread, biscuits and brownies, giving us clues to follow in bakery or bakery products due to their similarity in ingredients and types of preparations. It is possible to develop food products based on Moringa Oleifera flour with acceptable sensory and nutritional properties when less than $20 \mathrm{~g}$ of this material is used, depending on the intended food product.

Most of the studies are on biscuits, however, the addition of Moringa oleifera can be found in meats, juices and yoghurts among others. The addition of Moringa oleifera in the food industry represents a great contribution to the nutritional value of products, which can be an interesting strategy that aims to improve the nutritional status and health of people, especially in places of extreme poverty or food scarcity. Moreover, it is an attractive factor for those who like to eat healthy and that a food product is more than just taste and meaning.

In conclusion, taking into account all aspects related to the level of plant utilization, this review reported that Moringa oleifera can be used in the production of nutrient-enriched bakery products with good storage quality and high consumer acceptance.

Author Contributions: Conceptualization, G.N.; methodology, G.N., P.G.M., R.P.; validation, G.N., R.P., P.G.M.; writing: preparation of the original draft and writing P.G.M., R.P., G.N.-Revision and edition, G.N., R.P., P.G.M.; display G.N.; supervision, G.N.; project management, G.N. All authors have read and agreed to the published version of the manuscript.

Funding: This research received no external funding.

Conflicts of Interest: The authors declare no conflict of interest.

\section{References}

1. Asensi, G.D.; Villadiego, A.M.D.; Berruezo, G.R. Moringa oleifera: Revisión sobre aplicaciones y usos en alimentos. Arch. Lat. De Nutr. 2017, 67, 86-97.

2. Olson, M.E.; Fahey, J.W. Moringa oleifera: Un árbol multiusos para las zonas tropicales secas. Rev. Mex. De Biodivers. 2011, 82, 1071-1082. [CrossRef]

3. José, J.; García, L. Moringa oleifera Lam.: Biología, Botánica, Propiedades Nutricionales y Medicinales; Universidad de Sevilla: Sevilla, Spain, 2016.

4. Singh, N. Panchakarma: Cleaning and Rejuvenation Therapy for Curing the Diseases. J. Pharmacogn. Phytochem. 2012, 1, 1-10. Available online: www.phytojournal.com (accessed on 27 January 2021).

5. Sanjay, P.; Dwivedi, K. Shigru (Moringa Oleifera Lam.): A Critical Review. Int. J. Ayu. Pharm. Chem. 2015, 3. Available online: www.ijapc.com (accessed on 28 January 2021).

6. Folkard, G.; Sutherland, J. Moringa oleifera un árbol con enormes potencialidades. Traducido De Agrofor. Today 1996, 8, 5-8.

7. Rani, N.Z.A.; Husain, K.; Kumolosasi, E. Moringa genus: A review of phytochemistry and pharmacology. Front. Pharmacol. 2018, 9, 108. [CrossRef] [PubMed]

8. Ma, Z.F.; Ahmad, J.; Zhang, H.; Khan, I.; Muhammad, S. Evaluation of phytochemical and medicinal properties of Moringa (Moringa oleifera) as a potential functional food. S. Afr. J. Bot. 2020, 129, 40-46. [CrossRef]

9. Padilla, C.; Valenciaga, N.; Crespo, G.; Gonzalez, D.; Rodriguez, I. Agronomical requirements of Moringa oleifera (Lam.) in livestock systems. Livest. Res. Rural Dev. 2017, 29, 218.

10. García, M.G. Moringa Oleifera: Árbol Multiusos de Interés Forestal Para El Sur de la Peninsula Ibérica; Departamento de ingeniería y gestión Forestal y Ambiental, Universidad Politécnica de Madrid: Madrid, Spain, 2016; pp. 1-12.

11. Martínez, L.; Bastida, P.; Castillo, J.; Ros, G.; Nieto, G. Green alternatives to synthetic antioxidants, antimicrobials, nitrates, and nitrites in clean label Spanish Chorizo. Antioxidants 2019, 8, 184. [CrossRef]

12. Nieto, G.; Martínez, L.; Castillo, J.; Ros, G. Hydroxytyrosol extracts, olive oil and walnuts as functional components in chicken sausages. J. Sci. Food Agric. 2017, 97, 3761-3771. [CrossRef] [PubMed]

13. Martínez, L.; Jongberg, S.; Ros, G.; Skibsted, L.H.; Nieto, G. Plant derived ingredients rich in nitrates or phenolics for protection of pork against protein oxidation. Food Res. Int. 2020, 129, 108789. [CrossRef] [PubMed]

14. Martínez, L.; Castillo, J.; Ros, G.; Nieto, G. Antioxidant and antimicrobial activity of rosemary, pomegranate and olive extracts in fish patties. Antioxidants 2019, 8, 86. [CrossRef] [PubMed] 
15. Oyeyinka, A.T.; Oyeyinka, S.A. Moringa oleifera as a food fortificant: Recent trends and prospects. J. Saudi Soc. Agric. Sci. 2018, 17, 127-136. [CrossRef]

16. Sagona, W.C.J.; Chirwa, P.W.; Sajidu, S.M. The miracle mix of Moringa: Status of Moringa research and development in Malawi. S. Afr. J. Bot. 2020, 129, 138-145. [CrossRef]

17. Tobias, F.L. Moringa oleifera el Árbol de la Nutrición. Cienc. Y Salud Virtual 2012, 2, 130-138. Available online: http: / / trafficlight.bitdefender.com/info?url=http\%3A//revistas.curnvirtual.edu.co/journals/index.php/cienciaysalud/article/ view /70\&language=es_ES (accessed on 25 January 2021).

18. Norma, L.; Alfaro, C.; Martínez, I.W. Uso Potencial de la Moringa (Moringa oleifera, Lam) para la Producción de Alimentos; FonacytIncap: Guatemala City, Guatemala, 2008.

19. Olson, M.E. MORINGACEAE Martinov magnoli. Drumstick Tree Family. In Flora of North America, North of Mexico; Oxford University Press: Oxford, UK, 2010; Volume 7, pp. 167-169.

20. Paliwal, D.R.; Sharma, V.; Pracheta, D.R. A review on horse radish tree (Moringa oleifera): A multipurpose tree with high economic and commercial importance. Asian J. Biotechnol. 2011, 3, 317-328. [CrossRef]

21. Kumar, P.; Singh, K.; Kumar, A. Hepatoprotective Studies on Aerial Parts of Moringa oleifera Lam. on Carbon tetrachloride induced liver cell damage in albino rats. Ann. Biol. Res. 2010, 1, 27-35. Available online: https://www.scholarsresearchlibrary. $\mathrm{com} /$ articles/hepatoprotective-studies-on-aerial-parts-of-moringa-oleifera-lam-on-carbontetrachloride-induced-liver-celldamage-in-alb.pdf (accessed on 26 January 2021).

22. Castillo-López, R.I.; León-Félix, J.; Angulo-Escalante, M.Á.; Gutiérrez-Dorado, R.; Muy-Rangel, M.D.; Heredia, J.B. Nutritional and phenolic characterization of moringa Oleifera leaves grown in Sinaloa, México. Pak. J. Bot. 2017, 49, 161-168.

23. El-Massry, F.H.M.; Mossa, M.E.M.; Youssef, S.M. Moringa oleifera Plant "Value and Utilization in Food Processing". J. Agric. Res. 2013, 91, 1597-1609.

24. Gómez, A.V.; Angulo, K. Revision de las caracteristicas y usos de la planta moringa oleifera. Artic. De Revis. 2014, 22, 309-330.

25. Amaglo, N.K.; Bennett, R.N.; Lo Curto, R.B.; Rosa, E.A.S.; Lo Turco, V.; Giuffrida, A.; Lo Curto, A.; Crea, F.; Timpo, G.M. Profiling selected phytochemicals and nutrients in different tissues of the multipurpose tree Moringa oleifera L., grown in Ghana. Food Chem. 2010, 122, 1047-1054. [CrossRef]

26. Timilsena, Y.P.; Vongsvivut, J.; Adhikari, R.; Adhikari, B. Physicochemical and thermal characteristics of Australian chia seed oil. Food Chem. 2017, 228, 394-402. [CrossRef]

27. Abdulkadir, A.R.; Zawawi, D.D.; Jahan, M.S. Proximate and phytochemical screening of different parts of Moringa oleifera. Russ. Agric. Sci. 2016, 42, 34-36. [CrossRef]

28. Cuellar-Nuñez, M.L.; Luzardo-Ocampo, I.; Campos-Vega, R.; Gallegos-Corona, M.A.; González de Mejía, E.; Loarca-Piña, G. Physicochemical and nutraceutical properties of moringa (Moringa oleifera) leaves and their effects in an in vivo AOM/DSSinduced colorectal carcinogenesis model. Food Res. Int. 2018, 105, 159-168. [CrossRef] [PubMed]

29. Leone, A.; Spada, A.; Battezzati, A.; Schiraldi, A.; Aristil, J.; Bertoli, S. Cultivation, genetic, ethnopharmacology, phytochemistry and pharmacology of Moringa oleifera leaves: An overview. Int. J. Mol. Sci. 2015, 16, 12791-12835. [CrossRef]

30. Sánchez-Machado, D.I.; López-Cervantes, J.; Ríos Vázquez, N.J. High-performance liquid chromatography method to measure $\alpha$ and $\gamma$-tocopherol in leaves, flowers and fresh beans from Moringa oleifera. J. Chromatogr. A 2006, 111-114. [CrossRef] [PubMed]

31. Gómez, V.; Angulo, J.O. Revisión Las Características Y Usosde la Planta Moringa Oleífera. Sist. Inf. Científica 2014, $22,309-330$.

32. Leone, A.; Spada, A.; Battezzati, A.; Schiraldi, A.; Aristil, J.; Bertoli, S. Moringa oleifera Seeds and Oil: Characteristics and Uses for Human Health. Int. J. Mol. Sci. 2016, 17, 2141. [CrossRef]

33. Bhutada, P.R.; Jadhav, A.J.; Pinjari, D.V.; Nemade, P.R.; Jain, R.D. Solvent assisted extraction of oil from Moringa oleifera Lam. seeds. Ind. Crops Prod. 2016, 82, 74-80. [CrossRef]

34. Saini, R.K. Studies on Enhancement of Carotenoids Folic Acid Iron and Their Bioavailability in Moringa Oleifera and In Vitro Propagation; University of Mysore: Mysore, India, 2013.

35. Verma, K.S.; Nigam, R. Nutritional Assessment of Different parts of Moringa oleifera Lamm collected from Central India. J. Nat. Prod. Plant Resour. 2014, 4, 81-86. Available online: http:/ / scholarsresearchlibrary.com/archive.html (accessed on 26 January 2021).

36. Saini, R.K.; Shetty, N.P.; Giridhar, P. GC-FID/MS analysis of fatty acids in Indian cultivars of Moringa oleifera: Potential sources of PUFA. JAOCS J. Am. Oil Chem. Soc. 2014, 91, 1029-1034. [CrossRef]

37. Castro-López, C.; Ventura-Sobrevilla, J.M.; González-Hernández, M.D.; Rojas, R.; Ascacio-Valdés, J.A.; Aguilar, C.N.; MartínezÁvila, G.C. Impact of extraction techniques on antioxidant capacities and phytochemical composition of polyphenol-rich extracts. Food Chem. 2017, 237, 1139-1148. [CrossRef]

38. Rodríguez-Pérez, C.; Quirantes-Piné, R.; Fernández-Gutiérrez, A.; Segura-Carretero, A. Optimization of extraction method to obtain a phenolic compounds-rich extract from Moringa oleifera Lam leaves. Ind. Crops Prod. 2015, 66, 246-254. [CrossRef]

39. Coppin, J.P.; Xu, Y.; Chen, H.; Pan, M.H.; Ho, C.T.; Juliani, R.; Simon, J.E.; Wu, Q. Determination of flavonoids by LC/MS and anti-inflammatory activity in Moringa oleifera. J. Funct. Foods 2013, 5, 1892-1899. [CrossRef]

40. Saini, R.K.; Shetty, N.P.; Giridhar, P. Carotenoid content in vegetative and reproductive parts of commercially grown Moringa oleifera Lam. cultivars from India by LC-APCI-MS. Eur. Food Res. Technol. 2014, 238, 971-978. [CrossRef] 
41. Saini, R.K.; Shetty, N.P.; Prakash, M.; Giridhar, P. Effect of dehydration methods on retention of carotenoids, tocopherols, ascorbic acid and antioxidant activity in Moringa oleifera leaves and preparation of a RTE product. J. Food Sci. Technol. 2014, 51, $2176-2182$. [CrossRef] [PubMed]

42. Prakash, D.; Suri, S.; Upadhyay, G.; Singh, B.N. Total phenol, antioxidant and free radical scavenging activities of some medicinal plants. Int. J. Food Sci. Nutr. 2007, 58, 18-28. [CrossRef]

43. Singh, B.N.; Singh, B.R.; Singh, R.L.; Prakash, D.; Dhakarey, R.; Upadhyay, G.; Singh, H. Oxidative DNA damage protective activity, antioxidant and anti-quorum sensing potentials of Moringa oleifera. Food Chem. Toxicol. 2009, 47, 1109-1116. [CrossRef]

44. Liao, P.C.; Lai, M.H.; Hsu, K.P.; Kuo, Y.H.; Chen, J.; Tsai, M.C.; Li, C.-X.; Yin, X.-J.; Jeyashoke, N.; Chao, L.K.-P. Identification of $\beta$-Sitosterol as in Vitro Anti-Inflammatory Constituent in Moringa oleifera. J. Agric. Food Chem. 2018, 66, 10748-10759. [CrossRef]

45. Oladeji, O.; Taiwo, K.; Gbadamosi, S.; Oladeji, B.; Ishola, M. Studies on Chemical Constituents and Nutrients Bioavailability in Moringa oleifera Leaf and Seed. J. Sci. Res. Rep. 2017, 14, 1-12. [CrossRef]

46. Fejér, J.; Kron, I.; Pellizzeri, V.; Pl’uchtová, M.; Eliašová, A.; Campone, L.; Gervasi, T.; Bartolomeo, G.; Cicero, N.; Babejová, A.; et al. First report on evaluation of basic nutritional and antioxidant properties of moringa oleifera lam. From caribbean island of saint lucia. Plants 2019, 8, 537. [CrossRef]

47. Galuppo, M.; Nicola, G.; Iori, R.; Dell’Utri, P.; Bramanti, P.; Mazzon, E. Antibacterial Activity of Glucomoringin Bioactivated with Myrosinase against Two Important Pathogens Affecting the Health of Long-Term Patients in Hospitals. Molecules 2013, 18, 14340-14348. [CrossRef] [PubMed]

48. Martín, C.; Martín, G.; García, A.; Fernández, T.; Hernandez, E.; Puls, J. Potenciales aplicaciones de Moringa oleifera. Una revisión crítica. Pastos Forrajes 2013, 36, 137-149.

49. Anwar, F.; Latif, S.; Ashraf, M.; Gilani, A.H. Moringa oleifera: A food plant with multiple medicinal uses. Phytotherapy research: PTR. Phytother. Res. 2007, 21, 17-25. [CrossRef]

50. Williams, L.L. Moringa olefiera: Could this be an Answer to our Need for an Alternative to Fighting Drug-Resistance and Chronic Infections? Med. Aromat Plants 2013, 2, 1-3. [CrossRef]

51. Bhattacharya, A.; Tiwari, P.; Sahu, P.K.; Kumar, S. A review of the phytochemical and pharmacological characteristics of moringa oleifera. J. Pharm. Bioallied Sci. 2018, 10, 181-191.

52. Koul, B.; Chase, N. Moringa oleifera Lam.: Panacea to several maladies. J. Chem. Pharm. Res. 2015, 7, 687-707. Available online: http:/ /jocpr.com/vol7-iss6-2015/JCPR-2015-7-6-687-707.pdf (accessed on 25 January 2021).

53. Kumar, A.; Naaz, F.; Kushwaha, A.; Chaudhary, P.; Srivastav, P. Present review on phytochemistry, neutraceutical, antimicrobial, antidiabetic, biotechnological and pharmacological characteristics of Moringa oleifera Linn. BMR Phytomed. 2016, 2, 1-17. Available online: www.advancejournals.org (accessed on 28 January 2021).

54. Saini, R.K.; Sivanesan, I.; Keum, Y.S. Phytochemicals of Moringa oleifera: A review of their nutritional, therapeutic and industrial significance. 3 Biotech 2016, 6. [CrossRef] [PubMed]

55. Das, N.; Sikder, K.; Bhattacharjee, S.; Majumdar, S.B.; Ghosh, S.; Majumdar, S.; Dey, S. Quercetin alleviates inflammation after short-term treatment in high-fat-fed mice. Food Funct. 2013, 4, 889-898. [CrossRef]

56. Manguro, L.O.A.; Lemmen, P. Phenolics of Moringa oleifera leaves. Nat. Prod. Res. 2007, 21, 56-68. [CrossRef] [PubMed]

57. De Melo, G.O.; Malvar, D.D.; Vanderlinde, F.A.; Rocha, F.F.; Pires, P.A.; Costa, E.A.; de Matos, L.G.; Kaiser, C.R.; Costa, S.S. Antinociceptive and anti-inflammatory kaempferol glycosides from Sedum dendroideum. J. Ethnopharmacol. 2009, 124, 228-232. [CrossRef] [PubMed]

58. Arora, R.; Malhotra, P.; Sharma, A.; Haniadka, R.; Yashawanth, H.S.; Baliga, M.S. Medicinal Efficacy of Indian Herbal Remedies for the Treatment of Arthritis. In Bioactive Food as Interventions for Arthritis and Related Inflammatory Diseases; Elsevier Inc.: Amsterdam, The Netherlands, 2013; pp. 601-617.

59. Sashidhara, K.V.; Rosaiah, J.N.; Tyagi, E.; Shukla, R.; Raghubir, R.; Rajendran, S.M. Rare dipeptide and urea derivatives from roots of Moringa oleifera as potential anti-inflammatory and antinociceptive agents. Eur. J. Med. Chem. 2009, 44, 432-436. [CrossRef]

60. Zhao, S.; Zhang, D. Supercritical fluid extraction and characterisation of Moringa oleifera leaves oil. Sep. Purif. Technol. 2013, 118, 497-502. [CrossRef]

61. Panda, S.; Kar, A.; Sharma, P.; Sharma, A. Cardioprotective potential of N, $\alpha$-l-rhamnopyranosyl vincosamide, an indole alkaloid, isolated from the leaves of Moringa oleifera in isoproterenol induced cardiotoxic rats: In vivo and in vitro studies. Bioorg. Med. Chem. Lett. 2013, 23, 959-962. [CrossRef]

62. Chaudhary, K.; Chaurasia, S. Neutraceutical Properties of Moringa oleifera: A Review. Eur. J. Pharm. Med. Res. 2017, 4, 646-655.

63. Galuppo, M.; Giacoppo, S.; De Nicola, G.R.; Iori, R.; Navarra, M.; Lombardo, G.E.; Bramanti, P.; Mazzon, E. Antiinflammatory activity of glucomoringin isothiocyanate in a mouse model of experimental autoimmune encephalomyelitis. Fitoterapia 2014, 95, 160-174. [CrossRef] [PubMed]

64. Oluduro, O.A.; Aderiye, B.I.; Connolly, J.D.; Akintayo, E.T.; Famurewa, O. Characterization and antimicrobial activity of 4-( $\beta$-Dglucopyranosyl-1 $\rightarrow 4$ - $\alpha$-L-rhamnopyranosyloxy)-benzyl thiocarboxamide; a novel bioactive compound from Moringa oleifera seed extract. Folia Microbiol. 2010, 55, 422-426. [CrossRef] [PubMed]

65. Tesfay, S.Z.; Magwaza, L.S.; Mbili, N.; Mditshwa, A. Carboxyl methylcellulose (CMC) containing moringa plant extracts as new postharvest organic edible coating for Avocado (Persea americana Mill.) fruit. Scientia Horticulturae 2017, 226, 201-207. [CrossRef]

66. Jayawardana, B.C.; Liyanage, R.; Lalantha, N.; Iddamalgoda, S.; Weththasinghe, P. Antioxidant and antimicrobial activity of drumstick (Moringa oleifera) leaves in herbal chicken sausages. LWT Food Sci. Technol. 2015, 64, 1204-1208. [CrossRef] 
67. Khor, K.Z.; Lim, V.; Moses, E.J.; Abdul Samad, N. The In Vitro and In Vivo Anticancer Properties of Moringa oleifera. Evid.-Based Complementary Altern. Med. 2018, 2018, 1071243. [CrossRef] [PubMed]

68. Thapa, K.; Poudel, M.; Adhikari, P. Moringa oleifera: A Review Article on Nutritional Properties and its Prospect in the Context of Nepal. Acta Sci. Agric. 2019, 3, 47-54. [CrossRef]

69. Saralaya, M.G.; Patel, P.; Patel, M.; Roy, S.P.; Patel, A.N. Antidiarrheal activity of methanolic extract of Moringa oleifera lam roots in experimental animal models. Int. J. Pharm. Res. 2010, 2, 35-39.

70. Govardhan Singh, R.S.; Negi, P.S.; Radha, C. Phenolic composition, antioxidant and antimicrobial activities of free and bound phenolic extracts of Moringa oleifera seed flour. J. Funct. Foods 2013, 5, 1883-1891. [CrossRef]

71. Farooq, F.; Rai, M.; Tiwari, A.; Khan, A.A.; Farooq, S. Medicinal properties of Moringa oleifera. J. Med. Plants Res. 2012, 6, 4368-4374. Available online: www.ijesrr.org (accessed on 22 January 2021).

72. Sultana, B.; Anwar, F. Flavonols (kaempeferol, quercetin, myricetin) contents of selected fruits, vegetables and medicinal plants. Food Chem. 2008, 108, 879-884. [CrossRef] [PubMed]

73. Vongsak, B.; Sithisarn, P.; Gritsanapan, W. Simultaneous determination of crypto-chlorogenic acid, isoquercetin, and astragalin contents in moringa oleifera leaf extracts by TLC-densitometric method. Evid.-Based Complementary Altern. Med. $2013,2013$. [CrossRef]

74. Ferreira, P.M.P.; Farias, D.F.; Oliveira, J.T.D.A.; Carvalho, A.D.F.U. Moringa oleifera: Bioactive compounds and nutritional potential. Rev. Nutr. 2008, 21, 431-437. [CrossRef]

75. Mahajan, S.G.; Mehta, A.A. Suppression of ovalbumin-induced Th2-driven airway inflammation by $\beta$-sitosterol in a guinea pig model of asthma. Eur. J. Pharmacol. 2011, 650, 458-464. [CrossRef]

76. Ndong, M.; Uehara, M.; Katsumata, S.I.; Suzuki, K. Effects of oral administration of Moringa oleifera Lam on glucose tolerance in Goto-Kakizaki and wistar rats. J. Clin. Biochem. Nutr. 2007, 40, 229-233. [CrossRef]

77. Cheenpracha, S.; Park, E.J.; Yoshida, W.Y.; Barit, C.; Wall, M.; Pezzuto, J.M.; Chang, L.C. Potential anti-inflammatory phenolic glycosides from the medicinal plant Moringa oleifera fruits. Bioorg. Med. Chem. 2010, 18, 6598-6602. [CrossRef] [PubMed]

78. Fahey, J. Moringa oleifera: A Review of the Medical Evidence for Its Nutritional, Therapeutic, and Prophylactic Properties. Part 1. Trees Life J. 2005, 1-15. [CrossRef]

79. Shah, M.A.; Bosco, S.J.D.; Mir, S.A. Effect of Moringa oleifera leaf extract on the physicochemical properties of modified atmosphere packaged raw beef. Food Packag. Shelf Life 2015, 3, 31-38. [CrossRef]

80. Asare, G.A.; Gyan, B.; Bugyei, K.; Adjei, S.; Mahama, R.; Addo, P.; Otu-Nyarko, L.; Wiredu, E.K.; Nyarko, A. Toxicity potentials of the nutraceutical Moringa oleifera at supra-supplementation levels. J. Ethnopharmacol. 2012, 139, 265-272. [CrossRef] [PubMed]

81. Canett-Romero, R.; Arvayo-Mata, K.L.; Ruvalcaba-Garfias, N.V. Aspectos Tóxicos Más Relevantes de Moringa oleiffera oleífera y sus Posibles Daños. BIOtecnia 2014, 16, 36. [CrossRef]

82. Ashfaq, M.; Basra, S.M.A.; Ashfaq, U. Moringa: A Miracle Plant of Agro-forestry. J. Agric. Soc. Sci. 2012, 8, 115-122. Available online: http: / /www.fspublishers.org (accessed on 20 January 2021).

83. Rivas-Vega, M.E.; López-Pereira, J.L.; Miranda-Baeza, A.; Sandoval-Muy, M.I. Sustitución parcial de harina de sardina con Moringa oleifera en alimentos balanceados para juveniles de tilapia (Oreochromismossambicus x Oreochromisniloticus) cultivada en agua de mar. BIOtecnia 2012, 14, 3. [CrossRef]

84. Ogunsina, B.S.; Radha, C.; Indrani, D. Quality characteristics of bread and cookies enriched with debittered Moringa oleifera seed flour. Int. J. Food Sci. Nutr. 2011, 62, 185-194. [CrossRef]

85. Chizoba, N.N. Sensory Evaluation of Cookies Produced from Different Blends of Wheat and moringa Oleifera Leaf Flour. Int. J. Nutr. Food Sci. 2014, 3, 307. [CrossRef]

86. Rabie, M.M.; Faten, I.; Youssif, Y.; Ezz El-Ragal, N. Effect of Moringa oleifera Leaves and Seeds Powder Supplementation on Quality Characteristics of Cookies. J. Food Dairy Sci. J. 2020, 11, 65-73. [CrossRef]

87. Nutan Narwal, R.R. Nutritional evaluation and organoleptic acceptability of baked products based on blend flour (maize). Int. J. Curr. Res. 2017, 9, 52909-52912.

88. Dos Santos, A.F.R.; Pontes, E.D.S.; de Araújo, M.G.G.; Melo, P.C.M.F.; Viera, V.B.; Jerônimo, H.M.Â. Elaboração e caracterização física e físico-química de um brownie enriquecido com farinha da folha de Moringa (Moringa oleífera). Res. Soc. Dev. 2020, 9, e101973927. [CrossRef]

89. Kolawole, F.; Balogun, M.; Opaleke, D.; Amali, H. An Evaluation of Nutritional and Sensory Qualities of Wheat -Moringa Cake. Agrosearch 2013, 13, 87. [CrossRef]

90. El-Gammal, R.; Ghoneim, G.; ElShehawy, S. Effect of Moringa Leaves Powder (Moringa oleifera) on Some Chemical and Physical Properties of Pan Bread. J. Food Dairy Sci. 2016, 7, 307-314. [CrossRef]

91. Bolarinwa, I.F.; Aruna, T.E.; Raji, A.O. Nutritive value and acceptability of bread fortified with moringa seed powder. J. Saudi Soc. Agric. Sci. 2019, 18, 195-200. [CrossRef]

92. Devisetti, R.; Sreerama, Y.N.; Bhattacharya, S. Processing effects on bioactive components and functional properties of moringa leaves: Development of a snack and quality evaluation. J. Food Sci. Technol. 2015, 53, 649-657. [CrossRef]

93. Sengev, A.I.; Abu, J.O.; Gernah, D.I. Effect of Moringa oleifera Leaf Powder Supplementation on Some Quality Characteristics of Wheat Bread. Food Nutr. Sci. 2013, 4, 270-275.

94. Manaois, R.; Morales, A.; Abilgos-ramos, R. Acceptability, Shelf Life and Nutritional Quality of Moringa-Supplemented Rice Crackers. Philipp. J. Crop Sci. 2013, 38, 1-8. 
95. Moringa Nativa-18/12/2015 I FDA. Available online: https://www.fda.gov/inspections-compliance-enforcement-and-criminalinvestigations / warning-letters / moringa-nativa-12182015 (accessed on 26 January 2021).

96. Martínez, L.; Ros, G.; Nieto, G. Effect of natural extracts obtained from food industry by-products on nutritional quality and shelf life of chicken nuggets enriched with organic Zn and Se provided in broiler diet. Poult. Sci. 2020, 99, 1491-1501. [CrossRef]

97. Nieto, G.; Martínez, L.; Castillo, J.; Ros, G. Effect of hydroxytyrosol, walnut and olive oil on nutritional profile of Low-Fat Chicken Frankfurters. Eur. J. Lipid Sci. Technol. 2017, 119, 1600518. [CrossRef]

98. Nieto, G. A Review on Applications and Uses of Thymus in the Food Industry. Plants 2020, 9, 961. [CrossRef] [PubMed]

99. Wambebe, C. Moringa. In African Indigenous Medical Knowledge and Human Health; CRC Press: Boca Raton, FL, USA, 2018; pp. 165-192. 